\title{
An Evaluation of E-Money's Growth, Barriers, and Challenges to Build Green Finance on Post- Covid Era
}

\author{
Imanda Firmantyas Putri Pertiwi ${ }^{*}$, Rosana Eri Puspita ${ }^{2}$, Mohamed Asmy Byn Mohd Thas \\ Thaker $^{3}$, Septi Kurnia Pratiwi ${ }^{4}$ and Nur Huri Mustofa ${ }^{5}$ \\ ${ }^{1,2,5}$ Faculty of Islamic Economics and Business IAIN Salatiga, Indonesia \\ ${ }^{3}$ Kuliyyah of Economic and Management Science, International Islamic University Malaysia \\ ${ }^{4}$ Faculty of Islamic Economics and Business IAIN Surakarta, Indonesia
}

\begin{abstract}
Since paper money is one of the Covid-19 transmission media, a touchless alternative is needed. Electronic money (e-money) is the best alternative. This study analyzes the growth, barriers, and challenges of emoney as a new means of payment in Indonesia by raising an empirical study on the millennial generation. Data was collected through interviews with the managers of e-money issuer companies and 18 millennial e-money customers. Using qualitative methods, this research concludes that the strategy for developing e-money is to create innovations that can make it safer for users to meet their daily needs in the post-covid era. Increased promos and cashback at merchants who have collaborated with products issued is also the most favourite development strategy for customers. Emoney customers face obstacles faced by e-money customers include safety issues, limited merchants, unstable provider networks, and socio-cultural factors (the habit of using conventional cash payment methods). The challenge that e-money issuers face is competitors of similar products. Millennial Indonesia is an emerging market for e-money, and this study is the first qualitative study to bring together the topics of e-money, millennials, and green finance.
\end{abstract}

\section{Introduction}

Currently, the world is facing exceeding critical global ecological limits [1]. To overcome this problem, the financial communities also participated by initiating green finance. Green finance is financial investments in programs and initiatives for sustainable development, environmental goods, and policies that promote the growth of a more sustainable economy [2]. E-money as a fin-tech innovation is one of the practical steps financial regulators, supervisors, and government finance executives take to manifest inclusive green finance [3].

Support for the use of e-money has increased since the Covid-19 era. A study on the effect of banknotes and coins health risks, conducted even before the Covid-19 era, found that Staphylococcus, Salmonella, E. coli, and Staphylococcus aureus could be found in large quantities on banknotes collected from the hospital [4]. The COVID-19 epidemic, triggered

* Corresponding author: imanda.putri@iainsalatiga.ac.id 
by the SARS-CoV-2 virus, has increased the health threats associated with banknotes and coins. Even China, where the virus first spread, disinfected, and destroyed cash further to mitigate the spread of the coronavirus [5]. Exchanging digital currency by e-money, unlike exchanging cash, does not entail any physical interaction [6], so that touchless payment technologies are becoming a new lifestyle for Indonesian millennials in the Covid-19 era [7].

The millennial generation is described as those who were born between 1983 and 1998. Millennials are digital natives, and nearly all of their practices, including financial activities, are digital and internet-based [8]. Millennial tends a cashless society, ownership of e-wallets $(21.9 \%)$ and e-money $(11.5 \%)$ shows this trend [9]. There are 40 institutions licensed as emoney providers, 504,386 e-money machine readers across Indonesia, 43,3 million e-money users, and 128.2 trillion e-money volume of the transaction as of November 2019 [10]. Ovo, Gopal and Dana are the three most popular e-wallet platforms, while the most popular e-cash is Flazz, e-mOney, and Brizzi. However, a single person can own many e-wallets or e-cash platforms [10].

The use of e-money rose considerably in 2020 as the Covid year in Indonesia. Compared to the volume circulated in 2019, the number of e-money in circulation in 2020 was 432 million, a $47.9 \%$ rise [11]. Even so, the circulation of e-money is still dominated by the uppermiddle-class society (Hidayah \& Alvionita, 2020). Financial services authorities (Otoritas Jasa Keuangan-OJK) are trying to face the challenge of making e-money inclusive for all societies by making a roadmap for e-money penetration through accelerators, regulation and supervision, research, collaboration, talent, and consumer protection [12]. The roadmap also includes digital financial literacy [12].

Uneven deployment of e-money in Indonesia allegedly due to some shortcomings. First, since Indonesia's infrastructure is still unequal, some parts face poor internet signals. Even though the internet is essential for e-money transactions. Second, e-money shopping is more wasteful. Users have no barriers to shopping because transaction processes are accessible, unlike when a customer needs to go to a store to buy offline or to an ATM to pass a sum of money to shop. Third, E-money is still considered unsafe. Moreover, the last is that not all convenience stores can transact using e-money [13].

In terms of e-money publishers, the biggest challenge in developing e-money is risk control and marketing management [14]. Customer data leakage, transaction denial, malware attacks, and malfunctions are some of the security risks that may arise [14]. E-money developers also face marketing challenges. The challenges stemming from Indonesians' cashusing habit. Although competition in the field of application-based e-money is getting tighter, the toughest competitors for e-money services today are not from fellow business actors but from the behaviour of Indonesians who still rely on cash transactions [15]. In addition, Indonesia lacks a legislative framework or political structure that governs e-money [16].

Some of the obstacles felt by both customers and e-money publishers need to be explored more deeply. It is hoped that the results of this review will be helpful in formulating other strategies for the development of e-money. Especially for the millennial generation, their perception of the growth, challenges, and opportunities of e-money needs to be known, especially in the post-covid era. Therefore, this study aims to examine the perceptions of emoney customers and publishers on the growth, challenges, and opportunities of e-money qualitatively.

The paper is organized as follows: Section 1 provides an introductory overview of emoney, focusing on how e-money relates to green finance and the millennial generation. Section 2 highlights the theory of e-money application to reach sustainable goals in post covid era. Section 3 outlines the method of this research; a qualitative method with source triangulation is chosen. Section 4 describes the results and discussion on the opinion of emoney publishers and e-money customers regarding developments, obstacles, and challenges to the use of e-money in the post-covid era as an effort to realize green finance. Section 5 
proffers the research implications, limitations, and recommendations for the policymakers on how to tap the potential of e-money.

\section{Literature Review}

\subsection{Green Finance}

Global Sectors to think green, including in the financial sector. The term green finance appears as a solution to think green in the financial sector. Green finance is a combination of environmentally friendly behaviour and the world of finance and business or the relationship between finance and ecology [17]. The green finance concept will encourage innovation and technology to reduce emissions and use renewable energy.

Green Finance in Indonesia was started in 1999 which was initiated by a central bank. These steps have been accommodated in green central banking activity [18]. In 1999 Bank Indonesia issued a regulation requiring banks to conduct environmental impact analyzes for large or high-risk loans. In 2005, Bank Indonesia issued a regulation requiring commercial banks to include environmental measures in assessing business prospects. In 2012, Bank Indonesia issued the Green Loan Model Guidelines for Mini Hydro Power Plant Projects. In 2014, Bank Indonesia developed a Voluntary Green Loan Model Guide for Mini-Hydro Power Projects for banks. In 2019, Bank Indonesia became a member of the NGFS.

Technology is a tool in green finance development [19]. The existence of technology will lead to innovations that will achieve the goals of doing green finance, solve problems that may arise, and support policies to achieve sustainability of green finance. In addition, innovation with technology will be a trigger inefficiency.

Green finance development relies heavily on individuals and business consumers such as producers, financial lenders, and investors [20]. Therefore, the discussion of green finance is limited to finance and the environment and extends from the market to policy aspects.

\subsection{E-Money}

E-E-money is defined as the stored value of money where a record of the funds is stored on an electronic device. Currently, e-money has become an emerging payment for business systems globally, including Indonesia [21]. E-money has similarities and differences with ewallets. What these two things have in common is that they are both digital payment systems. The difference between these two things is where the nominal value is stored at the top up by the user. For e-money, the nominal value topped up by the user is stored on a chip, while the e-wallet is stored on the server.

The development of e-money has experienced rapid growth with various innovations. The growing popularity of plastic cards has made Visa and MasterCard even more powerful and still dominate retail banking and electronic payment services used by many corporations, financial institutions, and government agencies [22].

For users, the use of digital payments such as e-money has several problems: fear of losing money, insecurity of mobile passwords, errors in the e-money system, and various other obstacles. Meanwhile, on the other hand, e-money and other digital payments are very useful to avoid the spread of covid because it reduces physical contact [23]. Therefore, awareness about the application of green finance with e-money as a countermeasure to the spread of covid is urgently needed. 


\section{Method}

This research is qualitative research that was executed by conducting structured interviews with twenty people. Two of them are the managers of e-money publishing companies, and the other eighteen are e-money users with millennial ages ranging from 20 39 years. People who have used e-money for at least a year are eligible to understand further using e-money properly. Salatiga has four districts, each of which is represented by four to five respondents. Salatiga was chosen as the test site since Salatiga has received an award as a "smart city" from the Kompas Research and Development Center in 2018 [24], although formally, the government wants to declare itself as a smart city in 2021 [25]. One of the indicators of a smart city is that the government supports the development of e-money by allowing residents to pay municipal taxes and levies with e-money.

This study uses the manual data analysis from the data obtained, transcript, encode, query, annotate, and map research data as was done in. This research will conduct content analysis. To clarify the interpretation from the chosen text results, content analysis employs three techniques (conventional, directed, and summative approaches) [26]. This research adopts the summative approach. This method entails counting main terms or words from the records and then explaining them. Meanwhile, the research model will look like the image below:

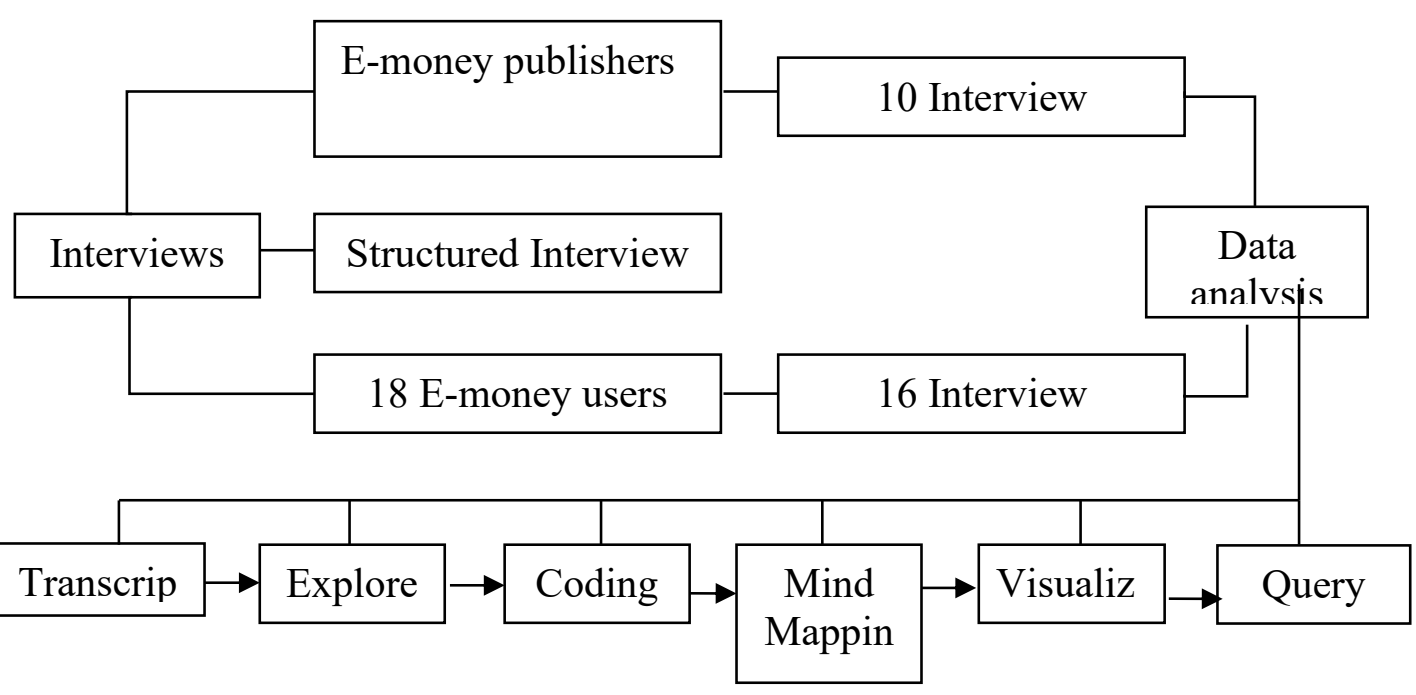

Fig. 1 Research Model.

To obtain data, this study was conducted using a semi-structured interview such as that conducted by Rabionet (2011). The first step in conducting a semi-structured interview according to Rabionet (2011) is to design a question structure based on a literature review to determine the indicators of each question. In this research questions are formulated using the following indicators: 
Table 2. Variable Indicators.

\begin{tabular}{|c|c|c|}
\hline & Variables & Indicators \\
\hline 1 & $\begin{array}{l}\text { Respondents Demographic } \\
\text { Information }\end{array}$ & $\begin{array}{l}\text { Publisher: name of the company, position in the company, } \\
\text { length of he/she works in the company } \\
\text { Customer: profession, age, education level }\end{array}$ \\
\hline 2 & $\begin{array}{l}\text { E-money's } \\
\text { Information }\end{array}$ & $\begin{array}{l}\text { Publisher: The type of e-money issued by the respondent } \\
\text { company [28], the company's goal of issuing e-money [28], } \\
\text { the development of the respondent's e-money during the last } \\
5 \text { years [28], the development of e-money by the respondent } \\
\text { company before and post covid [29], Innovations made by } \\
\text { respondent companies' e-money in response to covid [29]. } \\
\text { Customer: Respondents' knowledge of e-money [30], the } \\
\text { type of e-money used by respondents [28], the purpose of } \\
\text { respondents using e-money [28], the history of the use of e- } \\
\text { money by respondents for the last } 5 \text { years [28], the use of e- } \\
\text { money respondents pre and post covid [7] respondents' } \\
\text { awareness that e-money can minimize the risk of covid } \\
\text { transmission [7]. }\end{array}$ \\
\hline 3 & $\begin{array}{l}\text { E-money } \\
\text { information }\end{array}$ & $\begin{array}{l}\text { Publisher and customer: Security [28], infrastructure [28], } \\
\text { legal formal [28], socio-cultural [28]. }\end{array}$ \\
\hline 4 & $\begin{array}{l}\text { E-money challenges } \\
\text { information }\end{array}$ & $\begin{array}{l}\text { Publisher: Competitor companies [31], marketing [31]. } \\
\text { Customer: Discounts [32], explicit fees [32], merchants } \\
\text { [32]. }\end{array}$ \\
\hline
\end{tabular}

\section{Result and Discussion}

\subsection{Respondents Demographic Information}

The number of people that took part in this study was twenty. Two of the managers of emoney publishing companies are the general manager of Bank Mandiri (publisher of emoney) with more than 6 years of experience and the branch manager of Bank Syariah Indonesia (publisher of Tap cash Hasanah) also with more than 6 years of experience. While the millennial customer has chosen are ten junior millennials (21-28 years old) and eight senior millennials (29-36 years old). The typical job among junior millennial respondents is college students ( 7 persons), while others already work as employees ( 3 persons). At the same time, the occupations of senior millennial respondents are quite diverse; some work as civil servants ( 3 persons), as entrepreneurs ( 2 persons), private employees ( 2 persons), and others (1 person). We code our respondents as follows: P1 denotes Bank Mandiri manager, P2 denotes Bank Syariah Indonesia manager, $\mathrm{C} 1$ through $\mathrm{C} 10$ denotes junior millennial customers, and $\mathrm{C} 11$ through 18 denotes senior millennial customers.

\subsection{E-money's Growth Information}

In Indonesia, the growth of e-money has been rapid during the previous five years. The two publishers that participated in this survey agreed on this statement. Bank Syariah Indonesia achieved a 35 per cent rise. At the same time, Bank Mandiri respondents did not expressly specify the rise of e-money over the previous five years. However, he did say that 70 per cent of the 483 million e-money customers were "e-money Mandiri" users. The publisher's response is in line with the customer's responsibility. 17 of the 18 customer 
respondents said they had increased their use of e-money in the previous five years. Since the covid-19 outbreak, they have felt this surge even more. Some of the reasons that underlie the increased use of e-money during the pandemic are to avoid exposure to the Covid 19 virus by reducing direct contact with other people. Furthermore, because the epidemic drives people to stay at home, they are forced to utilize online shopping sites to substitute for offline shop. The policy of inter-regional restrictions by the government or what is known as largescale restrictions also supports this online shopping behaviour.

"I have become more frequent use of e-money, especially during a pandemic, when all transactions must be fully cashless and touchless." (C4)

On the other hand, 1 of the respondents stated that his usage of e-money decreased during the pandemic due to the decrease in his income as a result of the epidemic, which caused him to restrict his spending, both in cash or through e-money.

"Of course there is some pandemic effect, during a pandemic the level of spending is always minimized" (C7)

Even though the pandemic brought many changes in the behaviour of using e-money by customers, publishers said that the increase in e-money use during the pandemic was insignificant, only around $10-15 \%$. This publisher's answer makes sense when it comes to conflicting statements from customers. On the one hand, users do rely more on e-money to shop during the pandemic. However, on the other hand, some parties experience a decrease in income as a result of the pandemic, which automatically reduces their spending levels.

"Banks issued e-money to support government policy for cashless transactions during the pandemic; however, the increase was only around 10-15\%" (P2)

The only minor rise might be attributed to customers' motivation to utilize e-money for reasons other than health. Although 13 out of 18 respondents said one of the reasons they used e-money is for health reasons, the customers' top reasons were effectiveness, efficiency, and practicality.

"E-money is very simple and concise, it is also helping green finance to be environmentally friendly. By using e-money, my life feels more efficient" (C5)

\subsection{E-money's Barrier Information}

Although e-money has various benefits, in its implementation, there are still several obstacles and risks. The publishers said some of the risks they faced were the risk of theft (P1), hacking, and skimming (P2).

"The risk of theft is the greatest risk; therefore currently the mitigation is a maximum balance of only one million" (P1)

Security issues are the problem particularly concerned by customers. Error system (C1), default and double pay (C2), lost card (C3, C10), hacking (C2, C4, C7, C17, C18), forgot password $(\mathrm{C} 5, \mathrm{C} 11)$, data theft, and user privacy $(\mathrm{C} 6, \mathrm{C} 8, \mathrm{C} 15)$ are the reasons that they state.

"Careless use of e-money can lead to the leakage of personal information. For example, when we go to an ATM, we are instructed to cover the PIN when we press the pin, or the recommendation is always to change the pin to keep it safe. So do for e-money" (C15)

Security issues are not the only obstacle that users feel. Limited signals and inadequate devices are also obstacles to using e-money (C12). In addition, the limited number of merchants is also an obstacle (C14). Meanwhile, for respondent $\mathrm{C} 16$, currently, there are no obstacles in the use of e-money. Signal problems can be overcome by finding a location with a better signal or changing our provider. When it comes to the problem of risk, as long as we are smart users and not careless, all risks can be minimized. Moreover, about the limited merchants, he said that currently, in cities, almost on every street corner, there are e-money partner merchants, such as Shopee Pay, Ovo, Go-Pay, or Dana partners.

"All of these hazards and impediments must have been considered by e-money providers; we, the clients, do not need to be a worry." (C16) 
Even though the legality issue is fundamental, it does not appear to be a concern for the users. Only 5 participants out of 18 said they were certain that the usage of e-money was already regulated by the government, while 13 others were unsure or said that they didn't know. The fact is that the legality of e-money is governed by Law No. 11 (2008) and Bank Indonesia Regulation No. 11/12/PBI/2009 (P1)

"There is already a regulation from the government, and it has been regulated in the policies of each publisher as well" (C7)

The final issue discovered in this study is a socio-cultural one, in which individuals prefer to use cash rather than e-money (P2). This P2 statement may be true for rural areas, but for urban communities, particularly the millennial generation, as the respondents of this research, using e-money makes the feel more convenient. At least, the usage of both is gaining traction. 14 respondents said they prefer to use both (cash and e-money), 3 said they prefer e-money, and just 1 said they prefer cash.

The perception of the millennial generation of the city of Salatiga is very optimistic about e-money. The respondents' perceptions of usefulness and convenience were unanimously stated. $100 \%$ of respondents said that e-money made their life easier and more comfortable. $100 \%$ of respondents also stated that e-money is easy to use and learn. However, for the perception of security, only 13 out of 18 respondents answered that e-money is safe to use, 1 person said it was not safe, and the other answered doubtfully.

\subsection{E-money's Challenges Information}

The The obstacles discussed in the above sub-chapter create challenges for the publisher. Some of which were identified in this study were challenges from competitors, community literacy challenges, and user loyalty challenges. The main competitor of Bank Syariah Indonesia is BRI, due to BRI having a network that spreads to remote areas all over Indonesia (P2).

"BRI, they have a wide network that spreads to remote areas throughout all over Indonesia. We respond to this competition by improving our services and our e-money features." (P2)

While for Bank Mandiri, BCA is their main competitor (P1). P1 believes BCA to be Bank Mandiri's major competitor since BCA offers many products and services. Bank Mandiri's innovation to compete with BCA is to increase promos and discounts for the usage of e-money and other bank products. It turns out that the strategy for providing promos and discounts is highly effective. According to customers' responses, the majority of customers utilize e-money to obtain specific promos or discounts. 15 out of 18 respondents said they were interested in e-money's promos and would not hesitate to switch to other e-money platforms if they find their promos are more effective. Furthermore, if customers believe that utilizing an e-money platform is costly, they will not hesitate to abandon the e-money platform and go to another e-money platform. Customers identify several costs attached to an e-money, including administrative fees, different bank transfer fees, and top-up fees.

"There is usually an administration fee for updating the features. If the costs are too burdensome, then I switch to other platforms. As of now, I have 5 digital wallets, 2 e-cards, and 2 debit cards." (C4)

Besides improving product promos and features, another innovation made by publishers is by expanding their merchant network. Even though most of the respondents believe they have no issue locating e-money merchants near them, in this research case, the respondents are city dwellers in the millennial years. If different types of respondents are used in the study, different results may be obtained.

"Maybe for urban residents, finding merchants is not difficult, but we still need to improve the merchant network for rural communities. In addition, we will target all channels, 
including 1. Alfamart and Indomaret Retailer Networks; 2. Agreements with Toll Road Providers, and 3. Shopping Centers." (P1)

\section{Conclusions}

During the pandemic, the use of e-money has increased because it can minimize the spread of the Covid-19 virus. However, e-money in Indonesia has several barriers, such as security issues, system error, limited signal, and sociocultural use of cash in rural areas. Some of the challenges in growing e-money are literacy about e-money that is not yet high in society, consumer loyalty to an e-money product, administration fees that are sometimes considered high, and the lack of merchants that allow e-money to be used in rural areas.

\section{References}

[1] H. Ali, R. Abdullah, and M. Zaki Zaini, "Fintech and Its Potential Impact on Islamic Banking and Finance Industry: A Case Study of Brunei Darussalam and Malaysia," Int. J. Islam. Econ. Financ., vol. 2, no. 1, pp. 73-108, 2019.

[2] N. Lindenberg, "Definition of Green Finance," Ger. Dev. Inst., p. 3, 2014.

[3] U. Volz, P. Knaack, J. Nyman, L. Ramos, and J. Moling, "Inclusive Green Finance : From Concept To Practice," Kuala Lumpur London Alliance Financ. Incl. SOAS, Univ. London, 2020.

[4] E. Angelakis et al., "Paper money and coins as potential vectors of transmissible disease," Future Microbiol., vol. 9, no. 2, pp. 249-261, 2014.

[5] Z. Kakushadze and J. K. S. Liew, "Coronavirus: Case for digital money?,” arXiv, pp. 1-12, 2020.

[6] S. Pal, S. Chatterjee, S. Dey, S. Chowdhuri, and B. Neogi, "Mechanism to disinfect money to prevent COVID-19," J. Phys. Conf. Ser., vol. 1797, no. 1, 2021.

[7] D. Haryati, "Fenomena Cashless Society Pada Generasi Milenial dalam Menghadapi COVID-19," Bus. Innov. Entrep. J., vol. 3, no. 1, pp. 32-37, 2021.

[8] IDN Research Institute, “Indonesia Millennial Report 2020,” 2020.

[9] IDN Research Institute, "Indonesia Millennial Report 2019," 2019.

[10] Ipsos, "Indonesia 'The Next Cashless Society,"” 2020.

[11] Bank Indonesia, "Jumlah Uang Elektronik Beredar," 2021.

[12] OJK, "Kenali: Produk, Skema dan Harga Layanan Keuangan Digital," Indones. Financ. Serv. Auth., 2020.

[13] F. Faradela, "Kekurangan Penggunaan E-Money di Indonesia," https://tirto.id/kekurangan-penggunaan-e-money-di-indonesia-dhls, 2019. .

[14] A. Chesarina, "Digital Money: Peluang dan Tantangan bagi Bisnis Perbankan," https://www.kompasiana.com/chesarina13/5a0201daa4b06847fb7663e2/digitalmoney-peluang-dan-tantangan-bagi-bisnis-perbankan?page $=$ all\#sectionall, 2017 . .

[15] F. S. Dewi and T. Mola, "Transaksi Nontunai Jadi Tantangan Utama Pengembang E-Money," https://finansial.bisnis.com/read/20180702/90/811694/transaksinontunai-jadi-tantangan-utama-pengembang-e-money, 2018. .

[16] J. Guild, "The political and institutional constraints on green finance in Indonesia," J. Sustain. Financ. Invest., vol. 10, no. 2, pp. 157-170, 2020.

[17] M. S. Meo, M. Zaini, A. Karim, and O. Y. Abdullah, "The role of green finance in reducing $\mathrm{CO} 2$ emissions: An empirical analysis-NC-ND license (http://creativecommons.org/licenses/by-nc-nd/4.0/)," 2021.

[18] S. Dikau and U. Volz, "Central bank mandates, sustainability objectives and the promotion of green finance," Ecol. Econ., vol. 184, no. August 2020, p. 107022, 
2021.

[19] O. V. Andreeva, N. G. Vovchenko, O. B. Ivanova, and E. D. Kostoglodova, "Green finance: trends and financial regulation prospects," in Contemporary Issues in Business and Financial Management in Eastern Europe, 2018, pp. 9-17.

[20] Y. Wang and Q. Zhi, "The role of green finance in environmental protection: Two aspects of market mechanism and policies," Energy Procedia, vol. 104, pp. 311-316, 2016.

[21] H. M. Aji, I. Berakon, and A. F. Riza, "The effects of subjective norm and knowledge about riba on intention to use e-money in Indonesia," J. Islam. Mark., 2020.

[22] F. Dehghan and A. Haghighi, "E-money regulation for consumer protection," Int. J. Law Manag., vol. 57, no. 6, pp. 610-620, 2015.

[23] M. A. Daqar, M. Constantinovits, S. Arqawi, and A. Daragmeh, "The role of fintech in predicting the spread of covid-19," Banks Bank Syst., vol. 16, no. 1, pp. 1-16, 2021.

[24] Admin, "Bahas 'Smart Province', Dewan Kunjungi Salatiga 'Smart City,", https://dprd.jatengprov.go.id/2019/07/23/bahas-smart-province-dewan-kunjungisalatiga-smart-city/, 2019. .

[25] N. Haris, "DPRD Dukung Salatiga Jadi Smart City di 2021," https://jateng.tribunnews.com/2019/10/21/dprd-dukung-salatiga-jadi-smart-city-di2021, 2019. .

[26] S. Elo and H. Kyngäs, "The qualitative content analysis process," J. Adv. Nurs., vol. 62, no. 1, pp. 107-115, 2008.

[27] S. E. Rabionet, "How I Learned to Design and Conduct Semi-structured Interviews : An Ongoing and Continuous Journey," Qual. Rep., vol. 16, no. 2, pp. 563-566, 2011.

[28] D. Nassiry, "The Role of Fintech in Unlocking Green Finance: Policy Insights for Developing Countries," 2018.

[29] J. Z. Hafizd, "Peran Bank Syariah Mandiri (Bsm) Bagi Perekonomian Indonesia Di Masa Pandemi Covid-19," Al-Mustashfa J. Penelit. Huk. Ekon. Syariah, vol. 5, no. 2, p. 138, 2020.

[30] M. R. Firdaus, "E-Money Dalam Perspektif Hukum Ekonomi Syariah," Tahkim, vol. 14, no. 1, 2018.

[31] K. Widyastuti, P. W. Handayani, and I. Wilarso, "Tantangan dan Hambatan Implementasi Uang Elektronik di Indonesia: Studi Kasus PT XYZ," J. Sist. Inf., vol. 13, no. 1, p. 38, 2017.

[32] N. Falah and C. I. Setiawati, "E-Money Challenge in Disruption Era: Uncovering the Dilemma Issues from Consumers' Perspective," Sustain. Bus. Soc. Emerg. Econ., vol. 1, no. 2, pp. 109-122, 2019. 